\title{
Constructing Neoliberal Urban Democracy in the American Inner-City
}

Abstract: The neoliberalization of urban governance has profoundly problematized issues of "local" and "urban" democracy on both sides of the Atlantic. This paper explores the changing modalities of urban democracy under neoliberalism through a case study of Over-the-Rhine, Cincinnati. A historically maligned inner-city neighborhood, Over-the-Rhine is the locus for a concerted neoliberalizing gentrification drive and site of a coordinated resistance to marketoriented redevelopment. Three key processes of neoliberal restructuring are analyzed to highlight the centrality of contestations over local democracy for local economic development. Governance restructuring and the implementation of key spatial imaginaries are argued to produce a neoliberal articulation of urban democracy that discursively legitimizes development from above via an understanding of the neighborhood as a physical environment, usurping preexisting grassroots organizations conceptualizing Over-the-Rhine as a social structure. 


\section{Constructing Neoliberal Urban Democracy in the American Inner-City}

I worry a lot because the political will of this city; they have a different design for Overthe-Rhine and there are no real processes that involve neighborhood people. How, all of a sudden, did they get the authority to plan our neighborhood? (interview, Over-the-Rhine Community Organizer, 2005).

\section{Neoliberalism/Democracy}

"Democracy" is a pliable and contested concept, and its relationship to capitalism, particularly its neoliberal articulation, is both complex and contradictory. Numerous intellectual traditions from liberal desires to curb the negative effects of popular sovereignty, through deliberative and participatory calls for public engagement in the political process, to radical and revolutionary approaches aiming to undermine/overthrow the perpetuation of social inequality ${ }^{1}-$ theoretically attempt to optimize the social, political and economic conditions of democratic "majority rule". Yet despite democratic theory's "many faces," the ascension of neoliberalism from the intellectual margins to position of political-economic orthodoxy has been accompanied by a hegemonic coupling with a distinctly liberal conceptualization of democracy (Johnston and Glasmeier, 2007; Purcell, 2008).

Neoliberalism and liberal democratic theory, although subject to numerous internal debates, both draw from the liberal tradition, with its concern for individual liberty crystallized through a sharp delineation between the public and private sphere ${ }^{2}$. Neoliberalism, as a political-

\footnotetext{
${ }^{1}$ For an insightful review, see Purcell (2008, chapter 2), also Andrews and Turner (2006).

${ }^{2}$ See Hackworth (2007, chapter 1); Jessop (2002); and Purcell (2008, chapter 2) for astute discussions on the development of, and relationship between, liberalism and neoliberalism.
} 
economic doctrine, extols the virtues of open, competitive markets - secured via financial and social deregulation - as a means of social organization. Individuals are then free to maximize their potential and express their opinions/desires through the mechanisms of the market, unfettered by state interference (Jessop, 2002). Comparably, liberal democracy aims to protect the individual from persecution by the majority and insure the formal equality of citizens within the public realm and sphere of exchange (Mill, 1998). Freedom and equality are secured through formal political and judicial institutions, free elections (with elected officials representing the people), and constitutional guarantees of individual rights (critically those relating to private property) (Harvey, 2005; Purcell, 2008). Intervention in the private sphere (out-with assuring individuals' rights) is viewed as infringing upon the freedom of citizens and the imperatives of economic growth through accumulation (Mitchell, 2005). Hegemonic neoliberal discourses thus construct democracy as co-constitutive and co-dependent with capitalism, with each securing the conditions of reproduction for the other ${ }^{3}$.

The experience of "actually existing" neoliberalism however, fundamentally problematizes this assertion (Brenner and Theodore, 2002; Harvey, 2005). Neoliberal politicaleconomic restructuring, Peck and Tickell (2002) suggest, occurs through two interrelated moments: (1) "roll-back" neoliberalization; the removal of protectionist state policies, attacks on welfare and social-collectivist institutions, and assaults on organized labor; and (2) "roll-out" neoliberalization; the purposeful construction of new state institutions and modes of governance

\footnotetext{
${ }^{3}$ Coate (2005) and Harvey (2005) argue the global spread of formal liberal-democratic institutions and elections, such as those in Palestine, Iraq and Afghanistan are integral components of neoliberalization.
} 
which reconfigure the state as facilitator, rather than regulator, of an expanding market ${ }^{4}$. Numerous recent studies have pointed to the extension of market relations and the privatization of many state functions as increasingly removing decision-making from the public sphere (Hackworth and Moriah, 2006; Miller, 2007; Swyngedouw, 2005). This is no more evident than in cities where the profound transformations of urban space and society engendered by neoliberalism have led to "a pervasive... sense that urban neo-liberalization threatens urban democracy" (Purcell, 2006, p. 1921).

Faced with the increased mobility of global capital, cities become co-opted into a race-tothe-bottom competition for capital investment, corporate headquarters and prized "creative citizens" (e.g. Florida, 2008). Economic growth and the commodification of urban space, particularly through unstable, crisis prone mechanisms of financialization, come to dominate urban planning and policy formation (Harvey, 2005). Within this paradigm, cities act as key locations for the deployment of neoliberal policy agendas: place-marketing; local tax abatements; public-private partnerships; and urban development corporations (Brenner and Theodore, 2002; Hackworth, 2007). Low (2004) thus notes neoliberal urban governance regimes tend towards increasing power for corporate capital to influence running of the city, and a movement away from directly accessible and accountable institutions. Under the auspices of neoliberal urbanization, the "messy, slow and inefficient" processes of democratic deliberation are "a luxury cities competing desperately for investment cannot afford" (Purcell, 2008, p. 3).

Yet behind a pervasive rhetoric of "there-is-no-alternative" rationalization, in liberaldemocratic societies, neoliberalization still requires a discourse of legitimacy, operationalized

${ }^{4}$ Keil (2009) has subsequently pointed to a third moment of "roll-with-it" neoliberalization to capture the normalization of neoliberal governmentalities and social formations. 
through particular socially constituted and politically relevant discourses and expressed through contingently varying state-institutional forms (Jessop, 2008, p. 10). In this context, the discursive connection established between neoliberalism and (liberal) democracy becomes paramount. "Democratic discourses" have played a prominent role in attempts to normalize neoliberal restructuring in both the United Kingdom (Waters, 2009; Burns, 2000) and North America (Basu, 2007; Boudreau, 2003; Keil, 2009) ; significantly in the construction of "citizens"” as economically-active “consumers” (Andrews and Turner, 2006; Burns, 2000; Hubbard, 2004).

This paper examines the construction of a neoliberal mode of urban democracy through a neighborhood case study of Over-the-Rhine, Cincinnati (figure 1). I analyze the institutional and discursive strategies deployed in the construction and normalization of neoliberal urban democracy through three key processes of urban governance restructuring: (1) institutional contestation and succession; (2) restructuring municipal government; and (3) privatizing and rescaling urban development. Governance restructuring and the production of political and discursive space are argued to be fundamental mechanisms legitimizing - and de-legitimizing particular social groups and their visions of neighborhood society and space in order to facilitate inward investment and capital accumulation.

This argument draws on in-depth interviewing and a discourse analysis of institutional websites and local media coverage. Interviews were conducted with six neighborhood-based political/development groups, three local realtors and property developers, and ten residents representing a cross-section of Over-the-Rhine's diverse population in order to provide a view of the neoliberalization-democracy problematic from the ground up. Over-the-Rhine offers an 
extreme case of contested neighborhood redevelopment ${ }^{5}$, yet its history of economic decline, racialized social tension, and current gentrification is representative of the experiences of numerous American inner-cities (see Wilson, 2007). In the following, I offer a brief history of the neighborhood.

\section{Over-the-Rhine, Cincinnati, Ohio}

The completion of the Miami-Erie Canal in 1837 stimulated rapid growth in central Cincinnati. The cheaper cost of land north of the waterway attracted manufacturing companies, warehousing, and successive influxes of European (1830-1900); Appalachian (1930-1950); and African-American (1960-80) immigrants, with “Over-the-Rhine" developing as a densely built and populated neighborhood over 300 acres adjacently north of Downtown Cincinnati (Miller and Tucker, 1998). The Miami-Erie Canal formed a physical and symbolic border between Overthe-Rhine and Downtown which continued to significantly demarcate the two districts, even after the Canal was drained in 1919 and replaced (with improved connectivity between Over-theRhine and the CBD) by Central Parkway in 1928 (Scheer and Ferdelman, 2001).

\footnotetext{
${ }^{5}$ A controversial report released $22^{\text {nd }}$ June 2009 by neighborhoodscout.com (a website offering data to insurance companies, homebuyers and developers to evaluate neighbourhoods) ranked Liberty and Central Parkway in Over-the-Rhine as the United States' "most dangerous neighbourhood" based on 2005-2007 "predicted” annual crime rates (WLWT News, 2009). Whilst the report conflicted with Cincinnati Police reports that marked a $36 \%$ reduction in crime in Police District 1 during 2004-2007, it received national attention, perpetuating the image of Over-the-Rhine as a violent ghetto (Baker, 2009; Konkol, 2009).
} 
During the 1950s-1960s, Over-the-Rhine escaped the urban renewal bulldozers that razed the neighboring West End to make way for Interstate-75 (Davis, 1991). Consequently, a nationally recognized concentration of Italianate architecture remains in the district. Yet, as with many American inner-cities, Over-the-Rhine experienced large-scale disinvestment and decline during the post-war period; largely resulting from suburbanization, "white flight" and deindustrialization (Beauregard, 2006). Over-the-Rhine's population dropped to 7,638 in 2000 (one-fifth that at the turn of the twentieth century) while the proportion of African-Americans increased from 39\% in 1970 to $77 \%$ in 2000 (Cincinnati City Council, 2002). The out-migration of people and capital, combined with rising levels of crime, substance abuse, poverty and blight, stigmatized Over-the-Rhine as an urban ghetto (Wilson, 2007).

Since the 1980s, the City and key corporate actors' rediscovery of Over-the-Rhine's historic architecture has renewed interest in revitalizing the neighborhood. A concerted drive to gentrify the area has begun to introduce significant variations in the class and racial composition of the resident population. Whilst Over-the-Rhine continues to be predominantly AfricanAmerican, younger and poorer than the rest of Cincinnati's metropolitan area, the deployment of an aggressive development agenda (premised on market-rate housing development, gentrification and the promotion of key cultural facilities ${ }^{6}$ ) has increased socio-economic and racial tensions in the neighborhood.

These antagonistic relations exploded in April 2001, thrusting Over-the-Rhine into the national spotlight. The death of Timothy Thomas, an unarmed African-American teen shot in an

\footnotetext{
${ }^{6}$ For example, developing studio and gallery space; preserving cultural and architectural amenities (i.e. renovating Findlay Market); and promoting Over-the-Rhine's cultural facilities including Cincinnati Music Hall and the School for the Creative and Performing Arts.
} 
Over-the-Rhine alleyway by a Cincinnati Police Officer, unleashed a week-long period of largescale, racially-charged urban unrest centered on the neighborhood. Liberal observers (in American political discourse) viewed the uprising as a "rebellion" against racial discrimination and socio-economic disenfranchisement (Flannery, 2006). However, for many conservative commentators the "Cincinnati Riots" illustrated the failings of social-welfarism and existing strategies for neighborhood revitalization, thus legitimizing the implementation of punitive social policies and market-rate development programs (e.g. Bronson, 2006; Mac Donald, 2001).

Community activists, politicians and business leaders (at a number of scales) have crystallized the contrasting visions of Over-the-Rhine's future in a confrontational network of governance and development organizations through which their own concerns may be articulated and acted on. However, the shifting power relations and restructuring imperatives of urban neoliberalization have profoundly reconfigured the modalities of democratic access and accountability available through the neighborhood's governance architecture, usurping participatory grassroots political action through the construction of neoliberal urban democracy.

\section{Neoliberalizing Democratic Access and Accountability in Over-the-Rhine}

\subsection{Institutional Contestation and Succession}

In response to Over-the-Rhine's socio-economic degeneration, local activists, led by-and-large by the charismatic Buddy Gray, mobilized in the latter 1970s as the Over-the-Rhine People's Movement to: (1) alleviate the neighborhood's decline; and (2) advocate on behalf of its politically and economically disenfranchised population. In alliance with the elected and officially recognized residents' organization, the Over-the-Rhine Community Council, the 
People's Movement established a network of non-profit organizations to provide social services for Over-the-Rhine (and Cincinnati's) most marginalized inhabitants. These include:

- the Drop Inn Center; (currently) the largest homeless shelter in Ohio;

- Over-the-Rhine Contact Center; providing legal advice;

- Peaslee Center; providing space for community and educational activities;

- Race Street Tenant's Organization Cooperative (ReSTOC) and;

- Over-the-Rhine Housing Network: a network of affordable housing developers, operators and advocates ${ }^{7}$.

Through a project of community-based revitalization (e.g. mobilizing homeless residents and volunteers to renovate derelict buildings to create affordable housing units), the People's Movement forwarded a model of neighborhood regeneration premised upon marshalling marginalized urban inhabitants to improve their own community and environment.

Through the latter 1970s and 1980s, their model of development shaped Over-the-Rhine socially and (to a limited extent) physically, in part due to the lack of government funding and large-scale private capital investment in the neighborhood. During the 1980s however, Over-theRhine's historic buildings, low property values and rents became of increasing interest to key corporate actors, politicians and private developers as a means to: (1) produce an attractive residential district as a significant asset in Downtown Cincinnati's regeneration; and (2) profit from investment in the de-valorized historic built environment (Weber, 2002).

\footnotetext{
${ }^{7}$ ReSTOC and Over-the-Rhine Housing Network merged in April 2006 to form Over-the-Rhine Community Housing in an attempt to streamline operations, better serve their constituents, and reduce competition for scarce resources (Cramer and Zdenek, 2006).
} 
In 1984, led by pro-business city councilor (and future Cincinnati vice-Mayor) Jim Tarbell, a small group of local businessmen and civic leaders established the Over-the-Rhine Chamber of Commerce, citing the lack of an institutional infrastructure facilitating private capital investment for the failure to address the "great needs and prospective opportunities of Over-the-Rhine" (Over-the-Rhine Chamber of Commerce, 2008). Now Cincinnati's largest neighborhood chamber of commerce, its expanded influence is evidenced through a 2004 partnership with the Greater Cincinnati Chamber of Commerce, and the establishment of an offshoot organization, the Over-the-Rhine Foundation that seeks to "enhance artistic expression, and embrace the diversity of culture which enriches this community" (Over-the-Rhine Foundation, 2005).

Tarbell has called attention to the People's Movement's inability to realize widespread social and spatial transformations in Over-the-Rhine as a means to undermine their project:

All I can say about Buddy [Gray] is that it didn't work. Regardless of his intentions and what drove him, the methods in terms of succeeding and providing a better environment for the city in general and low income people in particular was a disaster (c.f. Quinlivan, 2002).

Indeed, the continued presence of crime, blight and significantly, the April 2001 Riots have been deployed through the local media to delegitimize the People's Movement, depicting: (1) lowincome advocates as stifling investment to produce a "haven for the poor" (Quinlivan, 2002); and (2) Over-the-Rhine residents as "a people broken by alcohol and drug abuse" (Cincinnati Enquirer, 2006). The discursive and material marginalization of the People's Movement, in turn, forwards the neighborhood Chamber as the organization now representing Over-the-Rhine's interests and (incoming/gentrifying) residents; as a low-income advocate argued: 
[The Over-the-Rhine Chamber of Commerce] are speaking on behalf of Over-the-Rhine and their interests do not include low-income people. They can easily call up a Jim Tarbell or some other councilor and get the things they need and want; it's discrediting the Community Council (interview, Community Organizer, 2005).

Certainly, the Over-the-Rhine Chamber has actively sought to emphasize their position as political voice of the neighborhood. Their community meetings are marketed as open to everyone in the neighborhood (despite the Chamber's explicitly pro-business ideology) "so people understand that if you just come to the meetings, you have a voice and you're going to get results" (interview, Over-the-Rhine Chamber of Commerce representative, 2005).

The succession of neighborhood institutions is itself expedited by the socio-economic and demographic transition of residents in Over-the-Rhine. The political base of the People's Movement is significantly undermined by the perpetuation of crime and blight driving lowincome residents from the neighborhood (interview, Smith, 2005). As a result, the "Community Council is not as credible as it has been in the past... there are more people living here now that don't align themselves with the interests of low-income people" (interview, Community Organizer, 2005). Organizing grassroots mobilization and community-based redevelopment projects with low-income residents has consequently become more difficult for the People's Movement:

You're talking about people in this neighborhood who have a lot of other issues to deal with. It takes time, effort and resources to be able to go beyond that and worry about politics and the neighborhood in general... Residents don't have time, they're economically stressed [and] we're barely able to fund social services, let alone consciousness raising (interview, Drop Inn Center representative, 2005). 
In contrast, a local realtor argued incoming homeowners are more apt to become involved in community redevelopment, claiming; "people buying in Over-the-Rhine and Downtown have a different mindset to other people. They buy because the loft is cool, that's true, but they buy because they really care about Downtown and Over-the-Rhine" (interview, Realtor, 2005).

This is not to conflate the Over-the-Rhine Chamber with incoming residents, or infer that all incoming residents support, or only become involved with, projects organized by the Overthe-Rhine Chamber/Foundation ${ }^{8}$. Furthermore, residents moving into the gentrifying districts of Over-the-Rhine have a claim to representation in the neighborhood, yet the top-down establishment of the new pro-market development institutions marks an important moment of hostile neoliberalization (Swyngedouw, 2005). Low-income residents and advocates have dominated the Community Council and as such, market-rate development proponents had been unable to steer the future direction of neighborhood through the existing democratically elected political channels. Creating a new, pro-business institutional infrastructure has opened new forms of, and channels for, participation in the neighborhood but this access is selective.

${ }^{8}$ A resident young professional claimed development in Over-the-Rhine "only serves the developers" and was wary that the Chamber's constituency was "a lot of the people doing the developing, [those] with an economic stake in gentrification". (interview, Brown, 2005). However, interviews with incoming/gentrifying residents revealed many actively support the Chamber's ideology and initiatives but also become involved with projects organized by the People's Movement. For example, two resident interviewees both volunteered at the Drop Inn Center and participated in Over-the-Rhine Foundation litter picks (interviews, Brown, 2005; Doe, 2005). 
Moreover, it comes at the expense of the established Community Council, negating a public space through which disenfranchised residents are politically represented.

\subsection{The Neoliberalization of Municipal Government}

The new institutional landscape and channels of political representation created at the neighborhood scale are operationalized and legitimated through their embedding within Cincinnati's wider governance infrastructure. Here, the position of Cincinnati City Council deserves particular attention.

\section{Restructuring City Hall (and its Priorities)}

Clashes between the People's Movement and neighborhood Chamber derailed much potential development and investment in Over-the-Rhine throughout the 1980s and 1990s. Cincinnati City Council became increasingly frustrated with the resulting stalemate; particularly the unwillingness of the People's Movement to cooperate with private development proposals (May and Monk, 2003).

Between 1997 and 2002, City Council established a spark of hope for bipartisan development through commissioning a community-led Comprehensive Plan for Over-the-Rhine (Cincinnati City Council, 2002). To a large degree, this successfully brought the divergent neighborhood factions around the same table. Whilst the Comprehensive Plan remained somewhat generalized, after several years' exhaustive engagement in the community most participants could point to beneficial aspects of their individual visions incorporated in the final document. Within Over-the-Rhine, the Comprehensive Plan showed potential, yet before either the momentum generated through the community planning process could be capitalized on, or the messy logistical details could be hashed out in practice, the Comprehensive Plan was 
effectively shelved in 2003 when the City collapsed its Planning Commission into the Economic Development Department:

The 2002 Plan is a really good document with a lot of really good ideas but it was just a vision statement when the City effectively said they didn't want anything to do with implementing it. It was an opportunity lost (interview, Over-the-Rhine Foundation representative, 2005).

Extirpating the institutional space of the Planning Commission and establishing in lieu a private development corporation charged with central city revitalization (see Section 3.3) evidences a shift in the priorities and practices of the municipal government. In order to pursue a specific model of development, not only is community planning rejected, but broader democratic interactions are scaled back. This has fundamental ramifications for grassroots political mobilization as a mechanism for neighborhood revitalization (Elwood, 2002; Fraser, 2004). Through the marginalization of the local community's input, the sticky work of participatory or deliberative democracy, reflected in the impasse between People's Movement and neighborhood Chamber, is bypassed by a moment of "creative destruction" in Cincinnati's governance architecture (Brenner and Theodore, 2002). Indeed, the 2002 Comprehensive Plan's demise marked the last moment where many neighborhood organizations and residents believed they could exercise a significant degree of self-determination (interview, Drop Inn Center representative, 2005).

Political support for the devolution of City planning authority was widespread in both political and business communities (see Leibovitz and Salmon, 1999). Interviewees criticized City Council in particular for excessive bureaucracy, "incompetence" and lacking the leadership vision and skills to implement the 2002 Comprehensive Plan (interviews, Property Developer, 
2005; Over-the-Rhine Foundation representative, 2005). It would be remiss to accuse the City of malevolently reshaping local government in an attempt to stimulate capital investment, however ruthlessly this disciplines the urban poor (see Mitchell, 1997). Cincinnati is embedded within a wider, neoliberalizing framework of governmental and financial institutions that have impinged upon its operational capacity. Funding cutbacks filtering from the federal and state governments have restricted the City, forcing a retraction from previous commitments to organizing and funding social services. However, the municipal government's (in)effectiveness/incompetence both real and perceived - have been assertively utilized to rationalize the "roll-back" of the state and the "roll-out" of a neoliberal policy framework.

The proliferation of calls for minimal state interference in urban governance, regeneration and social service provision has done much to discredit grassroots low-income organizations and strategies. Diskin and Dutton (2002) note that the Drop Inn Center and ReSTOC in particular have been portrayed as barriers to development, forwarded as “a 'stockpiler' of buildings, a bulwark against revitalization and an economic mix." Rather than contextualizing the capacity of the People's Movement to achieve improvements in Over-the-Rhine - which given the lack of available funds and labor in a hostile operating environment have included some significant successes - these organizations have been charged with perpetuating neighborhood decline (Mac Donald, 2001; Quinlivan, 2002). Their limitations discursively support the "roll-out" of alternative neoliberal development logics and governmental rationales which argue social service facilities, such as the Drop Inn Center, "are going to have to be moved" to enable economic development and neighborhood revitalization (interview, Over-the-Rhine Chamber of Commerce representative, 2005). 


\section{Accessing City Council}

Despite its perceived limitations, during the 1960s and 1970s, low-income advocacy organizations viewed Cincinnati City Council as (relatively) "progressive," open and accessible to both the general public and local interest groups (interview, Community Organizer, 2005). However, coinciding with the City's withdrawal from social service and funding commitments, direct lobbying and protest during official Council meetings have become increasingly restricted. In large degree a reaction to angry confrontations between Cincinnati's African-American community and the Cincinnati Police Department in council hearings during the lead up to April 2001's Riots (Gottbrath, 2001, see MacDonald et al., 2007), City Council introduced a series of rules regulating the conduct of public meetings. Low-income community organizations argued these restrictions limit public access to elected officials:

We have lost a lot, with public spaces and ever since civil unrest happened in April 2001; you could use to go to City Hall, raise an issue, raise some ruckus really, but after that incident, they really changed (interview, Community Organizer, 2005).

You used to have issues, and speakers for and against; now [City Council] limit the number of speakers, they limit the time to two minutes... There's now no forum now where I can air my two cents (interview, Drop Inn Center representative, 2005).

Through restructuring public meetings, Cincinnati City Council has forced lobbying into alternative spaces in City Hall. Away from official public meetings, lobbyists have developed new practices to gain access to Cincinnati's political elites?:

\footnotetext{
${ }^{9}$ This has proved particularly important for low-income community advocates who claim agenda scheduling in Council meetings tends to marginalize both Over-the-Rhine and the People's
} 
We don't just rely on City Council meetings; sometimes we go before the meeting when [councilors] are going to be walking through the hallways to get to their chambers and we'll try to corner them before meetings or after meetings... You have to confront people first and start a little bit of conflict and show them that we have power [but] it is difficult to get a lot of Council members to come back and meet with us (interview, Over-the-Rhine Contact Center representative, 2005).

Such backroom politicking has come with mixed results; whilst overall access to City Hall is curtailed, access to councilors has gradually become easier for groups such as the Contact Center as, over time, more politicians have become familiar with both the Center's projects and personnel. However, in moving from supply to demand-side access, councilors can be selective about whom they chose to meet with outside of public meetings. Thus, whilst representatives from the People's Movement noted a difficulty in arranging substantive meetings with City politicians, the Over-the-Rhine Chamber are "pretty high on the ladder when it comes to things involving Over-the-Rhine" and felt well connected in terms of consultation with the City and economic development agencies in Cincinnati (interview, Over-the-Rhine Chamber of Commerce representative, 2005).

\subsection{Privatizing and Rescaling "Neighborhood" Redevelopment}

In July 2003, building on the recommendations of the Cincinnati Economic Development Task Force, Cincinnati City Council formed and subsequently devolved responsibility for the regeneration of the city's urban core to the Cincinnati Center City Development Corporation

Movement, pushing their concerns to the back of proceedings (interviews, Drop Inn Center representative, 2005; Over-the-Rhine Contact Center representative, 2005). 
(3CDC). A private, non-profit corporation, 3CDC seeks to promote central Cincinnati as "a regional center of high value employment and real estate sustained by a diverse mix of housing, culture and entertainment" through facilitating development projects and brokering deals with the City and private investors (3CDC, 2008).

Whilst 3CDC meets operating costs through private donations from businesses and foundations, project financing is significantly supported by public funds. Capital funding for city center projects includes an investment by the City over five years of $\$ 100$ million from Tax Increment Funding (TIFs) supported by funding available through Empowerment Zones and Community Development Block Grants which Over-the-Rhine is eligible for (3CDC, 2008).

Private investment is structured through: (1) Cincinnati Equity Fund Ltd. (CEF), a private partnership modeled on traditional venture capitalist organizations. CEF seeks to support "real estate development and compliment the low-income housing market by providing market-rate housing units to create mixed-income neighborhoods", contributing \$45 million to Downtown projects since its establishment in 1995; and (2) Cincinnati New Market Fund (CNMF), created in 2004 to facilitate loans and equity investment for redevelopment projects in the CBD and Over-the-Rhine. CNMF, comprised of 13 leading Cincinnati corporations, forwarded in excess of \$90 million to compete for New Market Tax Credit Program dollars (awarded through the CDFI fund of the U.S. Treasury) in 2004. CNMF received \$50 million in federal tax credits and has applied for a second $\$ 50$ million award in 2008 to be invested in the redevelopment of Overthe-Rhine's Washington Park (3CDC, 2008).

As evidenced by CEF and CNMF, Cincinnati's corporate giants have thrown their weight behind 3CDC. The administrative structure of the corporation itself brings together CEOs and prominent members of Cincinnati's economic lynchpins, including representatives from several 
Fortune 500 companies in addition to the University of Cincinnati, Cincinnati Children's Hospital Medical Center and the Cincinnati Enquirer. 3CDC therefore wields considerable economic muscle and media support to enact their redevelopment plan for the central city. 3CDC's development mandate is premised upon a vital rescaling of urban regeneration that integrates Over-the-Rhine and Downtown within a wider project of redevelopment. Initially they identified three core development priorities; (1) "The Banks", consisting of the Ohio Riverfront between Cincinnati's football and baseball stadiums; (2) Fountain Square, the geographic and historical heart of Downtown Cincinnati; and (3) Over-the-Rhine. Early 3CDC materials framed Over-the-Rhine as "a landmark Cincinnati neighborhood", valued for "[boasting] one of the country's largest concentrations of Italianate architecture" and its proximity to the CBD (3CDC, 2005). Within Over-the-Rhine however, 3CDC has concentrated its redevelopment efforts on three census tracts extending only as far north as Liberty Street, (focusing on Washington Park and "the Gateway Quarter" ${ }^{\text {") }}$ ) subsequently bisecting the neighborhood's traditional territory.

Rearticulating the spatial frame of the "Center City" fundamentally alters the social, political and economic composition of inhabitants within the redevelopment district. As a result, Over-the-Rhine has effective been gerrymandered into the "center city", imposing corporate Cincinnati's interests onto the neighborhood. Rescaling neighborhood regeneration removes

${ }^{10}$ Since 2005, a $\$ 70$ million investment in phases I and II of the "Gateway Quarter" development has realized 98 housing (86 for-sale, 12 rental) and 14 commercial units. Phase III, a $\$ 30$ million project intended to develop over100 for-sale housing units and 15,000+ sq/ft of commercial space along southern Vine, Main, and Republic Streets broke ground in February 2008 (3CDC, 2008). 
direct democratic access for Over-the-Rhine residents to plan "their neighborhood", but moreover marginalizes the voices of local inhabitants' pursuing neighborhood-based community revitalization within a wider body-politic dominated by downtown corporate interests pushing gentrification. This becomes more problematic in terms of local participatory democracy as the devolution of planning authority has reconfigured the manner in which development plans are fashioned and implemented. Virtually every organization and resident interviewed concurred that they are unaware (to varying degrees) of 3CDC's plans until project details are finalized and presented to them.

Although 3CDC has managed to stimulate private investment, acquired significant parcels of land, and broken ground on several development projects in Over-the-Rhine, the corporation is a non-elected and therefore largely unaccountable organization. However, devolution and privatization from City Hall provides 3CDC with a seemingly democratic mandate that serves to usurp Over-the-Rhine inhabitants' right to self-determination. This is no more evidenced than in the aftermath of the 2002 Comprehensive Plan's demise. Two years after the community's plan was shelved, 3CDC introduced their own plan - focusing on Washington Park rather than Over-the-Rhine as a whole - first to the City, then to the neighborhood without any public involvement in the planning process (despite 3CDC's redevelopment of Fountain Square receiving several public hearings) (Dunlap, 2004).

Now, when either the City or 3CDC wish to implement plans or policies in the neighborhood, representatives from both the People's Movement and Over-the-Rhine Chamber of Commerce noted that they bypass the Over-the-Rhine Community Council to deal directly with the neighborhood Chamber. This serves to further legitimize the ideas and actions of market-rate development advocates and politically ostracizes the People's Movement; coercing 
them through a number of political and economic mechanisms into cooperation with organizations whose views diametrically oppose theirs (see May and Monk, 2003).

\section{Establishing the Foundations for Neoliberal Urban Democracy}

The predominant mode of democracy in Over-the-Rhine has shifted through the three processes of neoliberalization discussed above from a model grounded in grassroots praxis to a neoliberal formation operationalized within a new institutional landscape (see Gough, 2002; Swyngedouw, 2005). City elites increasingly eschew participatory democratic practices (e.g. community planning, grassroots neighborhood renewal) whilst extending (restructured) access to those sympathetic to market-rate development through alternative institutional spaces, both within Over-the-Rhine and at the wider "center city" scale. With this, liberal conceptions of representative/procedural democracy (evidenced by the Over-the-Rhine Chamber coming to "speak for" the neighborhood) and the property rights of capitalist developers (integral to 3CDC's model of development) increasingly trump alternative forms of participatory decisionmaking which had previously acted as barriers to local economic development (Purcell, 2006).

Underlying this shift, both implicitly and explicitly, has been the aggressive assertion of neoliberal political-economic ideology and practice. The liberal ontological division of public and private spheres - with the economy (and subsequently local economic development) increasingly construed as part of the private realm (Purcell, 2008, pp. 41-42) - has proved pivotal in the construction of a mode of urban democracy amenable to neoliberal urbanization. Of particular importance in this regard is the separation and subsequent privileging of (private) physical space for economic purposes over (public) social neighborhood space providing communal uses to Over-the-Rhine inhabitants (Merrifield, 2002). 
The competing visions for the future of the neighborhood are premised upon the valorization of disparate conceptions of Over-the-Rhine as a socio-spatial entity (Lefebvre, 1991). The People's Movement's engagement in Over-the-Rhine draws on a conception of the neighborhood as a localized social structure. Through establishing a network of organizations and social services, they have sought to enable neighborhood regeneration from within, raising the standard of living for the existing community of low-income, socially marginalized and politically disenfranchised inhabitants. In contrast, proponents of market-rate development view stimulating inward investment and extending market relations through the creation of a good business environment as the best strategy to tackle neighborhood decline. As such, they predominantly construct Over-the-Rhine as a physical territory and built environment. The need to stimulate development in Over-the-Rhine is then rationalized thusly:

Over-the-Rhine needs more attention because it is between our [Cincinnati's] two economic engines [Downtown and the University-Medical District]. Over-the-Rhine can be a beautiful bohemian neighborhood rather than a kind of beautiful ghetto. It changes the fortunes of the entire region (interview, Over-the-Rhine Foundation representative, 2005). This view presents the neighborhood as a space to be commodified, revalorized and marketed as an integral component of Cincinnati's regional development strategy and further implicitly posits a change in the resident population (from urban underclass to "bohemians") as an integral component of such regeneration (Weber, 2002; Slater, 2006).

Discursively disconnecting Over-the-Rhine as a social space and as a physical environment facilitates such a targeting of specific communities, organizations and socioeconomic groups as being responsible for causing and perpetuating neighborhood decline. This is evident in the pursuit of a coordinated attack on low-income advocacy organizations by the 
City and pro-business proponents. Two principle strategies have been employed to this end. Firstly, forwarding discursive constructions which: (1) associate the People's Movement with neighborhood decline; and (2) depict the neighborhood's low-income community as a parasitic drain on the city and its resources. This serves to discredit low-income residents for "[failing] to live up to the eligibility criteria [for citizens in] consumer society" (Hubbard, 2004, p. 666): as a local property developer commented, "Over-the-Rhine has been here for hundreds of years and it's never committed a crime, it's always been the people" (interview, Property Developer, 2005). Secondly, creating an alternative institutional infrastructure in the neighborhood: this not only opens new (selective) channels of political access, but also provides a pivotal foil legitimating the closure of existing democratic channels and concomitant ostracizing of lowincome residents and advocacy groups from the political and planning processes (Miller, 2007; Swyngedouw, 2005).

The capacity to usurp pre-existing grassroots organizations and (de)legitimize particular groups in Over-the-Rhine has been predicated upon the ability to produce space; both in terms of physical regeneration and forwarding dominant discursive representations of the neighborhood (Lefebvre, 1991). Neoliberalism is a distinctly spatial process of political-economic restructuring and reregulation (Brenner and Theodore, 2002), and, as Boudreau (2007) stresses, the production of new urban-political spaces and spatial imaginaries are vital strategic tools deployed in the normalization of neoliberalization. Within Over-the-Rhine, the ability to produce space is premised upon firstly, the economic capacity to invest in physical and social neighborhood development programs; and secondly, the ability to confer political legitimacy onto particular actors and agencies, including new institutions and the valorization of new scales (Boudreau, 2003). As such, the seemingly democratic mandate proved to 3CDC through the City's 
devolution of responsibility for planning the "center city" enables the rescaling of neighborhood development and the imposition of corporate Downtown capital onto Over-the-Rhine. This economic power, marshaled by $3 \mathrm{CDC}$, is then politically legitimized within the animation of central Cincinnati's new neoliberal governance landscape. The combination of urban governance restructuring and the forwarding of key socio-spatial and political discourses - both grounded in liberal theory - enables and legitimizes the re-articulation of urban democracy in Over-the-Rhine, marginalizing the concerns of vulnerable populations to facilitate accumulation.

\section{Concluding Remarks}

The struggle over political representation, access and accountability has been central to the "rolling out" of a neoliberal agenda in Over-the-Rhine. Rather than democracy being eroded by neoliberal policy implementation per se, or indeed necessarily co-constituted with neoliberal capitalism, the discourse of democracy itself has undergone a concomitant discursive and material transformation enabling the deployment and articulation of neoliberal urban democracy to be rolled out in favor of dominant political-economic interests (Harvey, 2005).

The case of Over-the-Rhine illustrates that the creation of new governance-institutional formations may establish alternative mechanisms of democratic practice yet there is nothing inherently progressive about them. The neighborhood's experiences under the imperatives of neoliberalization reveal a model of democracy that increasingly marginalizes socially disenfranchised populations, the urban poor, and those opposing market-based regeneration, negating their formal liberal equality in the public sphere. This neoliberal urban democracy draws on a powerful discourse of individual liberty and procedural representation, yet this is a selective process, premised on: (1) urban governance restructuring that privatizes and rescales 
physical and political space; (2) distinct mechanisms of social exclusion; (3) the privileging of private (property) rights; and (4) the aggressive separation of social and physical space.

If the city is to become a site of progressive democratic practice, and neighborhood regeneration is to be anything more than the reclamation of de-valorized urban spaces for economic purposes, public policy must critically engage the liberal separation of public and private spheres that intrinsically integrate physical and social space. Strategies for urban development must be extremely sensitive to the language and mechanisms available for public involvement in urban development, centering community-based development organizations and marginalized, disenfranchised urban inhabitants, materially and discursively, in the political process. Otherwise, the problems of urban decline will only be displaced, not resolved, with the interests of the most marginalized citizens usurped by calls for economic investment. 


\section{References}

3CDC. (2005) Year 2 progress report, October 2005, retrieved $12^{\text {th }}$ January 2006 from www.3cdc.org

3CDC. (2008) 3CDC webpage, retrieved $1^{\text {st }}$ December 2008 from www.3cdc.org

Andrews, R., and Turner, D. (2006) Modeling the impact of community engagement on local democracy, Local Economy, 21(4), 378-390.

Baker, J. (2009) Website: OTR most dangerous, [Electronic Version]. Cincinnati Enquirer, retrieved $9^{\text {th }}$ July 2009 from http://news.cincinnati.com.

Basu, R. (2007) Negotiating acts of citizenship in an era of neoliberal reform: the game of school closures, International Journal of Urban and Regional Research, 31(1), 109-127.

Beauregard, R. (2006) When America became suburban (Minneapolis: University of Minnesota Press).

Boudreau, J.-A. (2003) Questioning the use of "local democracy" as a discursive strategy for political mobilization in Los Angeles, Montreal and Toronto, International Journal of Urban and Regional Research, 27(4), 793-810.

Boudreau, J.-A. (2007) Making new political spaces: mobilizing spatial imaginaries, instrumentalizing spatial practices, and strategically using spatial tools, Environment \& Planning A, 39(11), 2593-2611.

Brenner, N., and Theodore, N. (2002) Cities and the geographies of "actually existing neoliberalism", Antipode, 34(3), 349-379.

Bronson, P. (2006) Behind the lines: the untold stories of the Cincinnati riots (Cincinnati: Chilidog Press).

Burns, D. (2000) Can local democracy survive governance?, Urban Studies, 37(5-6), 963-973. 
Cincinnati City Council (2002) Over-the-Rhine community final plan (Cincinnati: Cincinnati City Council).

Cincinnati Enquirer (2006, 11th May) Reviving Over-the-Rhine: “endangered” designation might save historic buildings, Cincinnati, Cincinnati Enquirer.

Coate, R. (2005) The promotion of democracy, Global Society, 19(4), 445-455.

Cramer, D., and Zdenek, R. (2006) A merger of equals, [Electronic Version]. National Housing Institute Shelterforce, retrieved $1^{\text {st }}$ July 2009 from http://www.nhi.org.

Davis, J. E. (1991) Contested ground: collective action and the urban neighborhood (New York: Cornall University Press).

Diskin, J., and Dutton, T. (2002) Cincinnati: a year later and no wiser, [Electronic Version]. National Housing Institute Shelterforce, retrieved $1^{\text {st }}$ July 2009 from http://www.nhi.org.

Dunlap, S. (2004, 14 July) Taking over the park, Cincinnati, CityBeat.

Elwood, S. (2002) Neighborhood revitalization through "collaboration": assessing the implication of neoliberal urban policy at the grassroots, GeoJournal, 58(2-3), 121-130.

Flannery, G. (2006, 5th-11th April) Long live the rebellion, Cincinnati, CityBeat.

Florida, R. (2008) Who's your city?: how the creative economy is making where to live the most important decision of your life (New York: Basic Books).

Fraser, J. (2004) Beyond gentrification: mobilizing communities and claiming space, Urban Geography, 25(5), 437-457.

Gottbrath, P. (2001, 14th March) Suit kicks off battle over racial profiling, Cincinnati Post.

Gough, J. (2002) Neoliberalism and socialization in the contemporary city: opposites, complements and instabilities, Antipode, 34(3), 405-426. 
Hackworth, J. (2007) The neoliberal city: governance, ideology and development in American urbanism (New York: Cornell University Press).

Hackworth, J., and Moriah, A. (2006) Neoliberalism, contingency and urban policy: the case of social housing in Ontario, International Journal of Urban and Regional Research, 30(3), 510-527.

Harvey, D. (2005) A brief history of neoliberalism (Oxford: Oxford University Press).

Hubbard, P. (2004) Revenge and injustice in the neoliberal city: uncovering masculinist agendas, Antipode, 36(5), 665-686.

Jessop, B. (2002) Liberalism, neoliberalism, and urban governance: a state-theoretical perspective, Antipode, 34(3), 452-472.

Jessop, B. (2008) State power. (Malden, MA: Polity Press).

Johnston, R., and Glasmeier, A. (2007) Neo-liberalism, democracy and the state: temporal and spatial constraints to globalization, Space and Polity, 11(1), 1-33.

Keil, R. (2009) The urban politics of roll-with-it neoliberalization, City, 13(2-3), 231-245.

Konkol, M. (2009, 23rd June) Chicago's most dangerous neighborhoods, Chicago Sun-Times.

Lefebvre, H. (1991) The production of space (Oxford: Blackwell).

Leibovitz, J., and Salmon, S. (1999) 20/20 vision?: Interurban competition, crisis and the politics of downtown development in Cincinnati, Ohio, Space and Polity, 3, 233-255.

Low, M. (2004) Cities as spaces of democracy: complexity, scale and governance, in C. Barnett and M. Low (Eds.), Spaces of democracy: geographical perspectives on citizenship, participation and representation (pp. 128-146) (Thousand Oaks, CA: Sage).

Mac Donald, H. (2001) What really happened in Cincinnati, [Electronic Version] City Journal, 11, retrieved $23^{\text {rd }}$ July 2008 from http://www.city-journal.org. 
MacDonald, J., Stokes, R., Ridgeway, G., and Riley, K. J. (2007) Race, neighborhood conflict and perceptions of injustice by the Police in Cincinnati, Urban Studies, 44(13), 25672585 .

May, L., and Monk, D. (2003, 21st November) ReSTOC's new free-market face, Cincinnati

Merrifield, A. (2002) Dialectical urbanism: Social struggles in the capitalist city (New York: Monthly Review Press).

Mill, J. S. (1998) On liberty, and other essays (Oxford: Oxford University Press).

Miller, B. (2007) Modes of governance, modes of resistance: contesting neoliberalism in Calgary, in H. Leitner, J. Peck and E. S. Sheppard (Eds.), Contesting neoliberalism: urban frontiers (pp. 223-249) (New York: Guildford Press).

Miller, Z., and Tucker, B. (1998) Changing plans for America's inner cities: Cincinnati's Overthe-Rhine and twentieth century urbanism (Columbus: Ohio State University Press).

Mitchell, D. (1997) The annihilation of space by law: the roots and implications of anti-homeless laws in the United States, Antipode., 29(3), 303-335.

Mitchell, D. (2005) The S.U.V. model of citizenship: floating bubbles, buffer zones, and the rise of the "purely atomic" individual, Political Geography, 24(1), 77-100.

Over-the-Rhine Chamber of Commerce (2008) Over-the-Rhine Chamber of Commerce homepage, retrieved $2^{\text {nd }}$ December 2008 from www.otrchamber.com.

Over-the-Rhine Foundation (2005) Over-the-Rhine Foundation mission statement, retrieved $12^{\text {th }}$ March 2005 from www.irhine.com.

Peck, J., and Tickell, A. (2002) Neoliberalizing space, Antipode, 34(3), 380-404.

Purcell, M. (2006) Urban democracy and the local trap, Urban Studies, 43(11), 1921-1941. 
Purcell, M. (2008) Recapturing democracy: neoliberalization and the struggle for alternative urban futures (New York: Routledge).

Quinlivan, L. (2002) Channel 9 News I-Team special report (transcript): "Visions of Vine Street", [Electronic Version] Channel 9 WCPO, retrieved $14^{\text {th }}$ March 2006 from http://www.wcpo.com/localshows/iteam/visionsofvine/1201_script.html.

Scheer, B., and Ferdelman, D. (2001) Inner-city destruction and survival: the case of Over-theRhine, Cincinnati, Urban Morphology, 5(1), 15-27.

Slater, T. (2006) The eviction of critical perspectives from gentrification research, International Journal of Urban and Regional Research, 30(4), 737-757.

Swyngedouw, E. (2005) Governance innovation and the citizen: the Janus face of governancebeyond-the-state, Urban Studies, 42(11), 1991-2006.

Waters, A. (2009) The state of local democracy in Britain, Local Economy, 24(3), 187-191.

Weber, R. (2002) Extracting value from the city: neoliberalism and urban redevelopment, Antipode, 34(3), 519-540.

Wilson, D. (2007) Cities and race: America's new Black ghetto (New York, NY: Routeledge).

WLWT News. (2009) Report: OTR nation's most dangerous neighborhood, [Electronic Version]. WLWT Channel 5 News, retrieved $9^{\text {th }}$ July 2009 from http://www.wlwt.com.

\section{Interviews}

Community Organizer, affiliated with the Over-the-Rhine Community Council and Peaslee Center, $2^{\text {nd }}$ June 2005, Cincinnati, Ohio

Drop Inn Center representative, $27^{\text {th }}$ May 2005, Cincinnati, Ohio

Over-the-Rhine Chamber of Commerce representative, $22^{\text {nd }}$ June 2005, Cincinnati, Ohio Over-the-Rhine Contact Center representative, $30^{\text {th }}$ June 2005, Cincinnati, Ohio 
Over-the-Rhine Foundation representative, $21^{\text {st }}$ June 2005, Cincinnati, Ohio

Property Developer, involved in projects throughout Greater Cincinnati and redeveloping properties in Over-the-Rhine, $26^{\text {th }}$ June 2005, Cincinnati, Ohio

Realtor, local realtor representing properties in Central Cincinnati and Northern Kentucky, $11^{\text {th }}$ June 2005, Covington, Kentucky

Brown, J., white male, 30, young professional, Over-the-Rhine condominium owner, 24 June 2005, Cincinnati, Ohio

Doe, J., white female, 28, graduate student, Over-the-Rhine condominium renter, 27 June 2005, Cincinnati, Ohio

Smith, J., white male, 60, Over-the-Rhine subsidized housing resident, 4 June 2005, Cincinnati, Ohio 


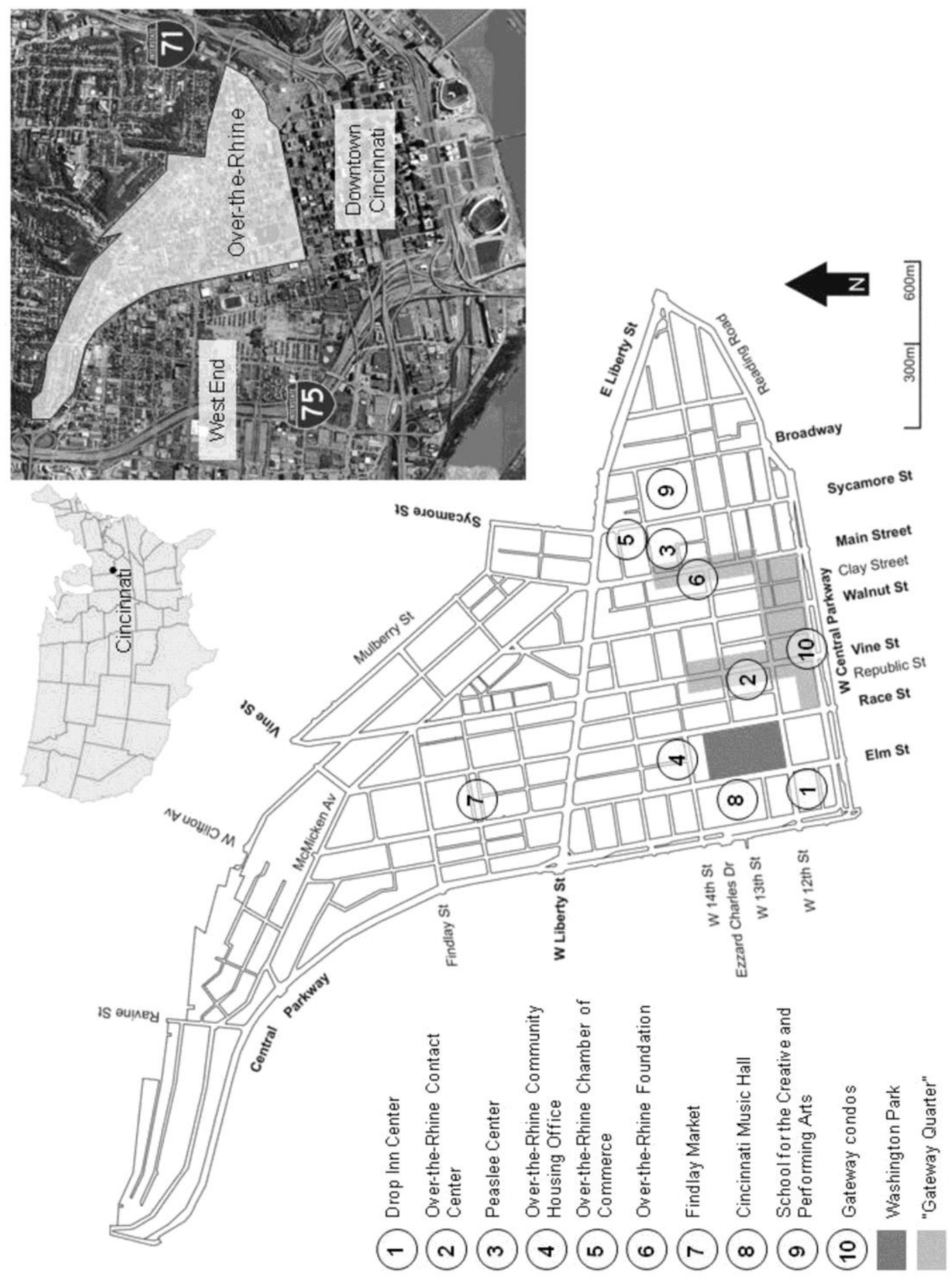

Figure 1: Over-the-Rhine, Cincinnati: including key institutions and districts discussed (source: base map adapted from Cincinnati City Council, 2002): Inlay: Over-the-Rhine in context (source: satellite image from Google Earth). 